\title{
Bioactive Compounds and Antimicrobial Activity of Glasswort Salicornia europaea
}

\author{
S. KARAN*, C. TURAN, M. K.SANGUN ${ }^{1}$ AND E. A. E. ELIUZ ${ }^{2}$ \\ Iskenderun Technical University, Faculty of Marine Science and Technology, Hatay $31200,{ }^{1}$ Hatay Mustafa Kemal University, \\ Faculty of Arts and Sciences, Department of Chemistry, Hatay 31060, ${ }^{2}$ Department of Food Technology, Vocational School of \\ Technical Sciences, Mersin University, Mersin 33110, Turkey
}

\section{Karan et al.: Biotechnological Analysis of Glasswort}

\begin{abstract}
This study aims to determine the chemical and physical composition and antibacterial activity of glasswort. Soxhlet extraction of Salicornia europaea was performed using hexane and analyzed by Gas chromatography-mass spectrometry. Alpha-tocopherol content was analysed by using liquid chromatography with tandem mass spectrometry. The elemental analysis was investigated by inductively coupled plasma mass spectrometry. The crystallographic texture and composition of powder samples were determined by X-ray diffraction. The minimum inhibition concentrations and inhibition zones extracts of Salicornia europaea were performed by spectrophotometric broth microdilution and disc diffusion methods, respectively, against 4 bacteria (Escherichia coli, Klebsiella pneumonia, Bacillus subtilis, Staphylococcus aureus) and 2 fungi (Candida albicans, Candida parapsilosis). Alpha-tocopherol quantity and oil content of Salicornia europaea were found to be $2.1 \pm 0.3 \mathrm{mg} / 100 \mathrm{~g}$ and $15.15 \%$, respectively. The detected minerals were also found as sodium 447, magnesium 51.98, K 45.86, Ca 14.27 ppm. The highest minimum inhibition concentration was $0.9 \mathrm{mg} / \mathrm{ml}$ against Escherichia coli in methanol extract $(\mathbf{p}<0.05)$. The highest mean inhibition zones diameter was $3.8 \mathrm{~mm}$ for methanol extracts against Bacillus subtilis $(\mathbf{p}<0.05)$. As a result, the extract and oil of Salicornia europaea can be used as potential bioactive and antimicrobial agents for pharmaceutical and cosmetics applications.
\end{abstract}

Key words: Antimicrobial, bioactive, raw material, glasswort, Salicornia europaea

The Glasswort Salicornia europaea (S. europaea) is a plant species in the family of spinach (Amaranthaceae) which is a sea related plant found in wet or sandy grounds, that is common in Atlantic and Mediterranean coasts. S. europaea is an annual halophytic plant $\mathrm{t}^{[1]}$ which is consumed by humans due to its taste. There are very similar and hardly distinguishable species of $S$. europaea in nature ${ }^{[2-3]}$ that seven species of the genus Salicornia were reported, Salicornia pusilla, Salicornia europaea, Salicornia obscura, Salicornia ramosissima, Salicornia nitens, Salicornia fragilis, Salicornia dolichostachya.

The plants mainly used for their medicinal or aromatic properties in pharmacy or perfumery are defined as medicinal and aromatic plants (MAPs) in the $\mathrm{EU}^{[4]}$, and thus, plant extracts are extensively used as active ingredients in cosmetics. The cosmetic concept is certainly very different from the past though some of the ingredients are still the same ${ }^{[5]}$. Herbal products claim to have less side effects, commonly seen with products

*Address for correspondence E-mail: karann.serpil@gmail.com containing synthetic agents. Therefore, the increasing demand for natural products and extracts is leading to the over-exploitation of natural plant resource ${ }^{[6]}$. In this regard, studies are being made on the search for new raw materials and the discovery of new crops. Especially, there are many plant species which are found in nature and are beginning to be used in cosmetics due to their content as antioxidant, anti-inflammatory, antiseptic, emollient, antiseborrheic, anti keratolytic activity and antibacterial ${ }^{[7]}$.

Up to date, to our knowledge, there has been no research on pharmaceuticals and cosmeceutical potential of S. europaea. Therefore, this study aims to investigate the chemical and physical composition and antimicrobial

This is an open access article distributed under the terms of the Creative Commons Attribution-NonCommercial-ShareAlike 3.0 License, which allows others to remix, tweak, and build upon the work non-commercially, as long as the author is credited and the new creations are licensed under the identical terms

Accepted 08 March 2021 Revised 03 January 2021 Received 25 October 2020 Indian J Pharm Sci 2021;83(2):238-246 
activity of $S$. europaea for pharmaceuticals and cosmeceutical applications.

\section{MATERIALS AND METHODS}

\section{Sample preparation and chemical analysis:}

Salicornia europaea samples were collected from Adana-Tuzla coastal areas and taken to the laboratory and washed and dried in air. For determination of moisture content, the sample was taken in a flat-bottom dish and kept in an air oven at $105^{\circ}$ for 2, 4, $6 \mathrm{~h}$ and allowed to cool at room temperature in a desiccator and then weighed. The procedure is repeated until successive weighing agrees to as constant weighing. The loss in weight was regarded as a measure of moisture content.

The air-dried and coarsely powdered, approximately 20 g. S. europaea was placed in Soxhlet extractor with a $100 \mathrm{ml}$ Hexane. The extracts were then concentrated to dryness under reduced pressure and controlled temperature by a rotary evaporator. The obtained oils were dried over anhydrous $\mathrm{CaCl}_{2}$ and then analyzed by triple quad Gas chromatography-mass spectrometry (GC-MS) that was also re-analyzed with GC-MS Hewlett Packard Gas collection device (GCD) equipped with a mass selective detector (MSD) for comparisons. The oils were analyzed by GC-MS using Hewlett Packard GCD (model 6890) and Hewlett Packard mass spectrometry (MS) (model 5972) equipped with a mass selective detector (MSD). An HP-5 column $(30 \mathrm{~m} \times 250 \mu \mathrm{m}$ i.d. $\times$ film thickness $0.25 \mu \mathrm{m})$ and HP 18 593B automatic injection system was used. $30 \mathrm{ml}$ of essential oils was transferred into $1 \mathrm{ml}$ of diethyl ether (Merck) and injected to the GC-MS sampling port. The chromatogram was produced by holding the oven temperature to $45^{\circ}$ for 5 min initially and then increasing the temperature to $130^{\circ}$ at a rate of $2^{\circ}$ per min followed by an increase at a rate of $3^{\circ}$ per min to $170^{\circ}$ and programmed to $220^{\circ}$ at a rate of $10^{\circ}$ per min then kept constant at $220^{\circ}$ for 5 min. MSD conditions were as follows: capillary direct interface temperature $250^{\circ}$, ionisation energy $70 \mathrm{eV}$, mass range, 33-330 amu, Electro-magnetic voltage (Atune +200 ), scan rate 5 scan per s. Helium was used as the carrier gas at a flow rate of $1.5 \mathrm{ml} / \mathrm{min}$. The components were identified by comparison of their mass spectra with Wiley GC-MS and National BIM Library. Relative percentage amounts of the separated compounds were calculated automatically from peak areas of the total ion chromatograms. The Kováts index of each compound was determined using C7-C40 Saturated Alkane Mixture, a certified reference material, which contains each $\mathrm{C} 7-\mathrm{C} 40$ component in a concentration of $1000 \mu \mathrm{g}$ in $\mathrm{ml}$ of hexane.

$1 \mathrm{~g}$ ground $S$. europaea was digested using a $12 \mathrm{ml}$ mixture of nitric acid/perchloric acid (8/2) (v/v) at the temperature of $100^{\circ}$ and then the obtained acidic solution was diluted to $20 \mathrm{ml}$ with ultrapure water and filtered through Whatman ${ }^{\circledR}$ to analyze by Inductively Coupled Plasma Mass Spectrometry (ICP-MS) (Agilent7500 ce Octopole Reaction System) for measuring elemental content of $S$. europaea.

About $9.82 \mathrm{~g}$ of fresh $S$. europaea was transferred into a $500 \mathrm{ml}$ beaker containing $200 \mathrm{ml}$ olive oil and incubated for 1 mo after which it was treated in an ultrasonic water bath for $1.5 \mathrm{~h}$. to analyze alphatocopherol content of the $S$. europaea samples using liquid chromatography with tandem mass spectrometry (LC/MS-MS). Official Method (2.432) International Union of Pure and Applied Chemistry (IUPAC), Thermo Scientific Quantum Access Model LC/MS-MS were used for the analysis.

Powdered $S$. europaea was attached to the specimen holder (stub), and elemental composition, the surface topography of the crystal structure by scanning the sample surface with high energy electron beam Scanning with an electron microscope type display Electron Microscope (SEM), energy dispersive X-ray analysis (EDX) were performed in order to know the chemical composition of $S$. europaea.

S. europaea was dried and powdered to a size below 22 microns in grinders for analyses. The powdered sample was placed inside of the aluminum sample holder to ready suitable for pressing vertically with the least orientation. The crystallographic texture and composition of powder samples were determined at standard angular resolutions up to $20 \times 20$ by X-Ray Diffraction (XRD).

\section{Antimicrobial analysis:}

Dried S. europaea was pulverized to obtain S. europaea extracts and the other fractions. The method was carried out with different residence times of the samples weighed $15 \mathrm{~g}$ and $30 \mathrm{~g}$ in parallel, and the retention time in the extraction was determined as 24,48 and $72 \mathrm{~h}$. Accordingly, powder of S. europaea was weighed (0.001 sensitivity) and put into beakers in which $100 \mathrm{ml}$ of ethanol, methanol, acetone and distilled water were added.

The antimicrobial activities of ethanol, methanol, acetone and aqueous extracts of $S$. europaea 
were investigated by using disc diffusion and spectrophotometric broth microdilution methods. For both methods, four bacterial and two fungal strains were used to investigate antimicrobial activities of the $S$. europaea extracts. The bacterial strains were two gram negative bacteria Escherichia coli (ATCC 25293) and Klebsiella pneumonia (K. pneumonia), and two gram positive bacteria Bacillus subtilis (B. subtilis) (ATCC 6633) and Staphylococcus aureus, and the fungal strains were Candida albicans (C. albicans) and Candida. parapsilosis (C. parapsilosis). The inoculums of microorganisms were prepared in $4 \mathrm{ml}$ Triptic Soy Broth for bacteria, $4 \mathrm{ml}$ Sabouraud Dextrose Broth for yeasts incubated at $37^{\circ}$ overnight. After $24 \mathrm{~h}$, the microorganism suspensions were adjusted to 0.5 McFarland standard turbidity and were kept at $+4^{\circ}$ to use for disc diffusion and spectrophotometric broth microdilution experiments ${ }^{[8]}$.

Spectrophotometric broth microdilution method for screening was performed on 96-well elisa plates, and firstly $50 \mu \mathrm{l}$ of Mueller Hinton Broth (MHB) medium were added into all wells. The two-fold serial dilutions of $50 \mu \mathrm{l}$ of $S$. europaea extract was made on all $\mathrm{x}$-axis along of plate. Negative and positive controls (Ampicillin for bacteria, Fluconazole for yeast) were performed in columns 11 and 12 . Then, $10 \mu \mathrm{l}$ culture of microorganisms was inoculated on all wells except medium control wells. All plates were incubated at $37^{\circ}$ for $24 \mathrm{~h}$ and the growth turbidity was measured at $600 \mathrm{~nm}$ and 415 bacteria and yeasts, respectively. As the calculation of minimum inhibition concentration (MIC) values, the optical density was read both before $\left(\mathrm{T}_{0}\right)$ and after $24 \mathrm{~h}$ incubation $\left(\mathrm{T}_{24}\right)$. For each plate, MIC was calculated using the following formulas (Eqn 1 and Eqn 2): The OD for each replicate at $\mathrm{T}_{0}$ was subtracted from the $\mathrm{OD}$ for each replicate at $\mathrm{T}_{24}{ }^{[9]}$. Percent of growth $(\%)=\mathrm{OD}_{\text {test }} / \mathrm{OD}_{\text {control }} \times 100$ Eq. 1. Percent of inhibition $(\%)=1-\mathrm{OD}_{\text {test well }} / \mathrm{OD}_{\text {corresponding control well }} \times 100 \mathrm{Eq}$. 2. Inhibition graph was plotted; $\mathrm{R}^{2}$ and then MIC (the lowest concentration of test material which results in $99.9 \%$ inhibition of growth) were calculated on the obtained linear slope ${ }^{[10-11]}$. Screening with the method of Disc Diffusion Assay, microorganism cultures assayed by McFarland 0.5 was spread onto $\mathrm{MH}$ (Mueller Hinton) agar plates. Paper discs (6 mm diameter) were placed on agar to load $20 \mu \mathrm{l}$ extracts prepared from $S$. europaea, the results were recorded in the growth inhibition zones $(\mathrm{mm})$ surrounding the disc using a digital caliper. All data related to antimicrobial activity were obtained by averaging the triplicate analyzes.

\section{RESULTS AND DISCUSSION}

The hexane-extracted oil yield of S. europaea cultivated was found to be $15.15 \%$. To find vitamin E (Alphatocopherol), S. europaea were extracted in hexane and olive oil to elucidate vitamin $\mathrm{E}$ concentration in the Liquid chromatography-mass spectrometry (LC-MS) that the alpha-tocopherol amounts were $2.1 \pm 0.3 \mathrm{mg}$ per $100 \mathrm{~g}$ with Hexane and $551.98 \mu \mathrm{g} / \mathrm{ml}$ with olive oil which showed that olive oil with $S$. europaea samples contains alpha-tocopherol much more than that the Hexane extraction (Table 1).

The Oleic acid, as a component of the essential oil of $S$. europaea, was found to be $36.55 \%$. The fatty acid composition (percent) of oil from glasswort (S. europaea) is presented in Table 2. The amount of sodium, magnesium, potassium and calcium $(\mathrm{Na}, \mathrm{Mg}$, $\mathrm{K}$ and $\mathrm{Ca}$ ) minerals in the $S$. europaea were found 447 , 51. 98, 45.86, $14.27 \mathrm{ppm}$ by ICP-MS. Alternatively, the results are also confirmed by EDX analyses in fig. 1 .

The crystallographic texture and composition were determined using XRD phase analysis, and Strontium Lanthanum Iron (III) Tin (IV) Oxide was found to be $54.5 \%$ (Table 3 ). Tin (IV) oxide is used as abrasive, bulking and opacifying agent in cosmetic product ${ }^{[12]}$. The surface morphology characterized by SEM and SEM image of $S$. europaea is given in micrograph enlarged scale bars of $40 \mu \mathrm{m}, 50 \mu \mathrm{m}$ and $400 \mu \mathrm{m}$ (fig. 2).

As a result of the disk diffusion method, the zone measurements of ethanol, methanol, acetone and

TABLE 1: LC/MS/MS RESULTS OF ALPHA TOCOPHEROL

\begin{tabular}{|c|c|c|c|c|}
\hline Sample Name & $\begin{array}{c}\text { Test/ (Analysis) } \\
\text { (Parameter) }\end{array}$ & Method & Unit & Result \\
\hline Olive oil & Alpha-tocopherol & $\begin{array}{c}\text { Determination of tocopherols and tocotrienols in vegetable oils } \\
\text { and fats by high performance liquid chromatography. Official } \\
\text { Method. } 2.432 \text {. IUPAC. }\end{array}$ & $\mu \mathrm{g} / \mathrm{ml}$ & 147.17 \\
\hline $\begin{array}{l}\text { Olive oil with } \\
\text { Salicornia } \\
\text { europaea }\end{array}$ & Alpha-tocopherol & $\begin{array}{c}\text { Determination of tocopherols and tocotrienols in vegetable oils } \\
\text { and fats by high performance liquid chromatography. Official } \\
\text { Method. } 2.432 \text {. IUPAC. }\end{array}$ & $\mu \mathrm{g} / \mathrm{ml}$ & 551.98 \\
\hline
\end{tabular}


TABLE 2: THE FATTY ACID COMPOSITION OF OIL FROM GLASSWORT (S. europaea) BY GC/MS

\begin{tabular}{lccccc}
\hline RT $($ min) & KI & Fatty Acids & Formula & MW & Amount (\%) \\
\hline 36.27 & 2315 & Palmitic acid & $\mathrm{C}_{16} \mathrm{H}_{32} \mathrm{O}_{2}$ & 256.42 & 5.12 \\
37.71 & 2387 & Palmitoleic acid & $\mathrm{C}_{17} \mathrm{H}_{32} \mathrm{O}_{2}$ & 268.43 & 3.27 \\
38.21 & 2411 & Oleik acid & $\mathrm{C}_{18} \mathrm{H}_{34} \mathrm{O}_{2}$ & 282.46 & 36.55 \\
49.38 & 3120 & 7-Octadecenoic acid, methyl ester & $\mathrm{C}_{19} \mathrm{H}_{36} \mathrm{O}_{2}$ & 296.49 & 11.31 \\
49.52 & 3128 & 8-Octadecenoic acid, methyl ester & $\mathrm{C}_{19} \mathrm{H}_{36} \mathrm{O}_{2}$ & 296.49 & 10.63 \\
49.94 & 3153 & 9-Octadecenoic acid, methyl ester & $\mathrm{C}_{19} \mathrm{H}_{36} \mathrm{O}_{2}$ & 296.49 & 13.77 \\
50.18 & 3167 & 9-Octadecenoic acid (Z)-, methyl ester & $\mathrm{C}_{19} \mathrm{H}_{36} \mathrm{O}_{2}$ & 296.49 & 2.73 \\
50.31 & 3175 & 10-Octadecenoic acid, methyl ester & $\mathrm{C}_{19} \mathrm{H}_{36} \mathrm{O}_{2}$ & 296.49 & 3.48 \\
50.41 & 3181 & Stearic acid & $\mathrm{C}_{19} \mathrm{H}_{38} \mathrm{O}_{2}$ & 298.50 & 4.07 \\
58.94 & 3553 & 11-Octadecenoic acid, methyl ester & $\mathrm{C}_{21} \mathrm{H}_{42} \mathrm{O}_{2}$ & 326.56 & 3.35 \\
61.40 & 3684 & 11-Eicosenoic acid, methyl ester & $\mathrm{C}_{21} \mathrm{H}_{40} \mathrm{O}_{2}$ & 324.54 & 3.42 \\
72.77 & 4285 & 2,6,10,14,18,22-Tetracosahexaene & $\mathrm{C}_{30} \mathrm{H}_{50}$ & 410.39 & 2.30 \\
\hline
\end{tabular}

RT: Retention Time; KI: Kovats Index; MW: Molecular Weight

TABLE 3: XRD RESULTS SHOWING COMPOUNDS CONTAINED IN S. europaea

\begin{tabular}{lccc}
\hline$\%$ & Ref.Code & Compound Name & Chem. Formula \\
\hline$* 16.6$ & $98-017-4207$ & Perovskite & $\mathrm{Mo}_{1} \mathrm{O}_{3} \mathrm{Sr}_{1}$ \\
$* 19.0$ & $98-004-4727$ & Calcium-alpha & $\mathrm{Ca}_{1}$ \\
$* 54.5$ & $98-007-2169$ & Strontium Lanthanum Iron(III) Tin(IV) Oxide & $\mathrm{Fe}_{1} \mathrm{La}_{1} \mathrm{O}_{6} \mathrm{Sn}_{1} \mathrm{Sr}_{1}$ \\
$* 9.9$ & $98-018-0530$ & Potassium Iron Dioxide & $\mathrm{Fe}_{1} \mathrm{~K}_{1} \mathrm{O}_{2}$ \\
\hline
\end{tabular}

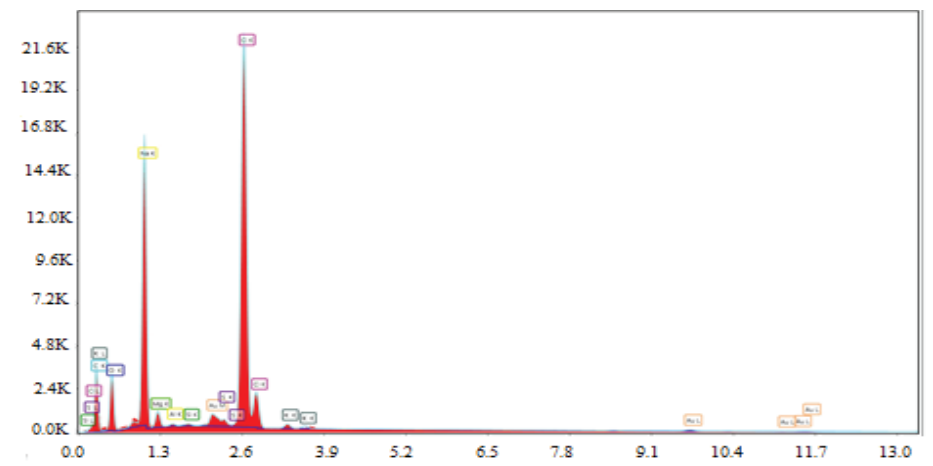

Fig.1: Graph of EDX analysis showing presence of elemental
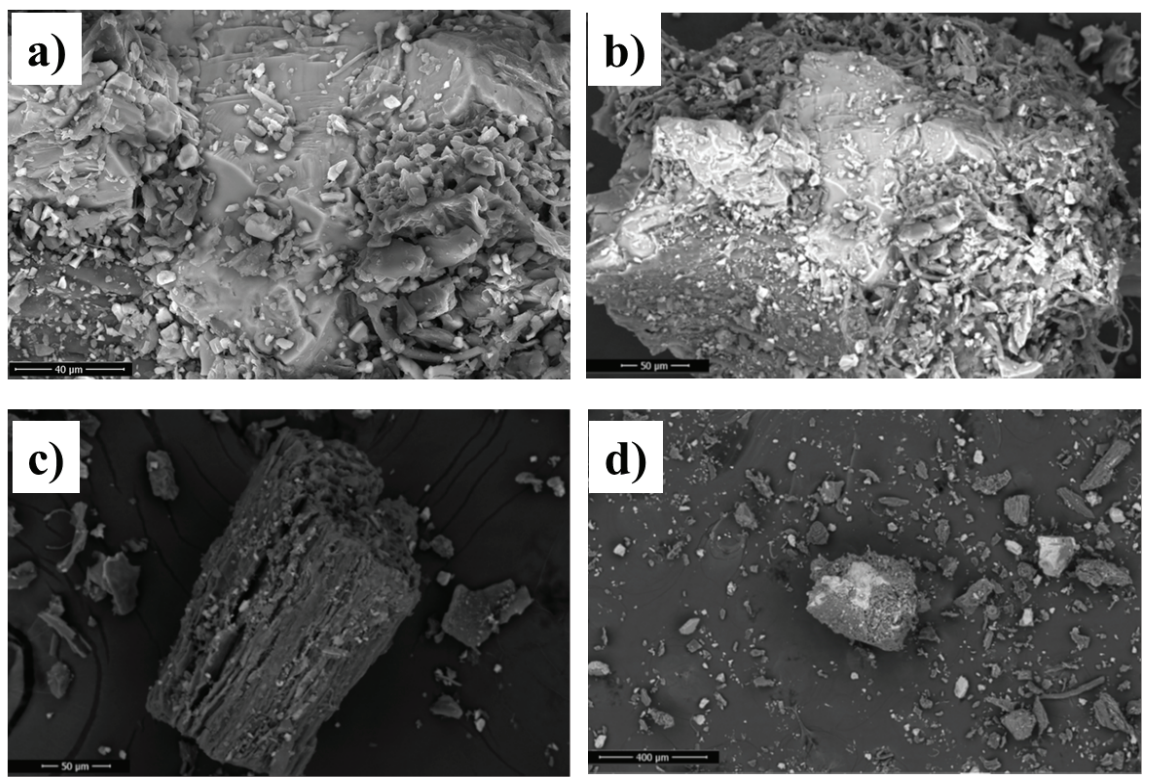

Fig. 2: SEM micrograph scale bars of $40 \mu \mathrm{m}$ for micrographs (a), $50 \mu \mathrm{m}$ (b), $50 \mu \mathrm{m}$ (c), $400 \mu \mathrm{m}$ (d). 
TABLE 4: INHIBITION ZONE DIAMETERS OF S. europaea EXTRACTS WITH E. coli, $K$. pneumoniae, B. Subtilis AND $S$. aureus ACCORDING TO THE DISC DIFFUSION METHOD

\begin{tabular}{|c|c|c|c|c|c|}
\hline \multirow[b]{2}{*}{ Weight (g) } & \multirow{2}{*}{$\begin{array}{c}\text { Extracts (h) } \\
\text { Acetone }\end{array}$} & \multicolumn{4}{|c|}{ Inhibition Zone $(\mathrm{mm})+$ SEM ${ }^{*}$} \\
\hline & & E. coli & K. pneumoniae & B. subtilis & S. aureus \\
\hline & 24 & $0.0^{\mathrm{a}}{ }_{ \pm 0,0}$ & $0.0^{\mathrm{a}} \pm 0,0$ & $0.0^{\mathrm{b}} \pm 0,0$ & $0.2_{ \pm 0,2}$ \\
\hline \multirow[t]{3}{*}{15} & 48 & $0.0^{\mathrm{a}}{ }_{ \pm 0,0}$ & $0.0^{a}{ }_{ \pm 0,0}^{a-0}$ & $0.5^{\mathrm{b}}{ }_{ \pm 0,5}^{-0,0}$ & $0.3^{\mathrm{bc}} \pm 0,3$ \\
\hline & 72 & $0.0^{\mathrm{a}} \underset{ \pm 0,0}{ \pm 0,0}$ & $0.0^{\mathrm{a}}{ }_{ \pm 0,0}^{ \pm 0,0}$ & $0.6^{\mathrm{b}}{ }_{ \pm 0,6}^{ \pm 0,5}$ & $0.0^{\mathrm{b}} \stackrel{ \pm 0,3}{ \pm 0,0}$ \\
\hline & 24 & $0.0^{\mathrm{a}}{ }_{ \pm 0,0}$ & $0.0^{a}{ }_{ \pm 0,0}^{-0,0}$ & $0.0^{\mathrm{b}}{ }_{ \pm 0,0}$ & $0.7^{\mathrm{a}}{ }_{ \pm 0,4}$ \\
\hline \multirow[t]{4}{*}{30} & 48 & $0.0^{\mathrm{a}}{ }_{ \pm 0,0}$ & $0.0^{a}{ }_{ \pm 0,0}$ & $0.0^{\mathrm{b}}{ }_{ \pm 0,0}$ & $1.1^{\mathrm{a}}{ }^{-0,0}, 0$ \\
\hline & 72 & $0.0^{a}{ }_{ \pm 0,0}$ & $0.0^{a}{ }_{ \pm 0,0}$ & $0.0^{\mathrm{b}}{ }_{ \pm 0,0}$ & $0.4^{\mathrm{bc}}{ }_{ \pm 0,4}$ \\
\hline & Ethanol & & & & \\
\hline & 24 & $0.0^{\mathrm{a}}{ }_{ \pm 0,0}$ & $0.0^{\mathrm{a}}{ }_{ \pm 0,0}$ & $1.9^{a}{ }_{ \pm 0,2}$ & $0.0^{\mathrm{b}}{ }_{ \pm 0,0}$ \\
\hline \multirow[t]{3}{*}{15} & 48 & $0.0^{\mathrm{a}}{ }_{ \pm 0,0}^{\mathrm{a}}$ & $0.0^{a}{ }_{ \pm 0,0}$ & $0.4_{ \pm 0,4}^{\mathrm{b}}$ & $0.0^{\mathrm{b}}{ }_{ \pm 0,0}$ \\
\hline & 72 & $0.0^{\mathrm{a}}{ }_{ \pm 0,0}^{-0,0}$ & $0.0^{a}{ }_{ \pm 0,0}$ & $0.2^{\mathrm{b}}{ }_{ \pm 0,2}^{-0,7}$ & $0.0^{\mathrm{b}}{ }_{ \pm 0,0}$ \\
\hline & 24 & $0.0^{\mathrm{a}}{ }^{20,0,0}$ & $0.0^{a}{ }_{ \pm 0,0}$ & 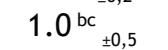 & $1.4^{\mathrm{add}}{ }_{ \pm 0,1}$ \\
\hline \multirow[t]{4}{*}{30} & 48 & $0.0^{\mathrm{a}}{ }_{ \pm 0,0}^{ \pm 0,0}$ & $0.0^{\mathrm{a}}{ }_{ \pm 0,0}^{ \pm 0,0}$ & $0.0^{\mathrm{b}}{ }_{ \pm 0,0}^{ \pm 0,0}$ & $0.3^{\mathrm{bd}}{ }_{ \pm 0,3}^{ \pm 0,1}$ \\
\hline & 72 & $0.0^{\mathrm{a}}{ }_{ \pm 0,0}$ & $0.0^{a}{ }_{ \pm 0,0}^{-0,0}$ & $0.0^{\mathrm{b}}{ }_{ \pm 0,0}^{ \pm 0,0}$ & $0.0^{\mathrm{b}}{ }_{ \pm 0,0}$ \\
\hline & Methanol & & & & \\
\hline & 24 & $1.5^{\mathrm{b}}{ }_{ \pm 0,4}$ & $0.0^{a}{ }_{ \pm 0,0}$ & $0.7^{\mathrm{b}}{ }_{ \pm 0,7}$ & $0.0^{\mathrm{b}}{ }_{ \pm 0,0}$ \\
\hline \multirow[t]{3}{*}{15} & 48 & $1.99^{\mathrm{b}}{ }_{ \pm 0,3}^{-2,7}$ & $1.3^{a}{ }_{ \pm 0,8}^{-0,0}$ & $1.3^{\mathrm{b}}{ }_{ \pm 0,7}^{\mathrm{b}, \mathrm{r}}$ & $0.9^{\mathrm{a}}{ }_{ \pm 0,5}$ \\
\hline & 72 & $2.1^{\mathrm{b}}{ }_{ \pm 0,7}$ & $1.4^{\mathrm{a}}{ }_{ \pm 0,9}^{ \pm 0,0}$ & $1.1^{\mathrm{bc}}{ }_{ \pm 0,7}$ & $1.0^{\mathrm{a}}{ }_{ \pm 1,0}$ \\
\hline & 24 & $0.9 \mathrm{ab}{ }_{ \pm 0,9}$ & $1.2^{a}{ }_{ \pm 0,6}$ & $2.0^{a}{ }^{a-0,1}$ & $0.0^{\mathrm{b}}{ }^{\mathrm{s}, \mathrm{0}, 0}$ \\
\hline \multirow[t]{4}{*}{30} & 48 & $1.5^{\mathrm{b}}{ }_{ \pm 0,2}$ & $1.7^{a}{ }^{=0,0,9}$ & $3.8^{a}{ }_{ \pm 0,6}$ & $1.9^{a}{ }^{a-0,2}$ \\
\hline & 72 & $0.0^{\mathrm{a}}{ }^{20,0,0}$ & $2.4^{a}{ }_{ \pm 1,7}$ & $2.7{ }^{a c}{ }^{a 0,6}$ & $1 \cdot 5^{a c}{ }_{ \pm 0,2}$ \\
\hline & Aqueous & & & & \\
\hline & 24 & $0.0^{\mathrm{a}}{ }_{ \pm 0,0}$ & $0.0^{\mathrm{a}}{ }_{ \pm 0,0}$ & $0.0^{\mathrm{b}}{ }_{ \pm 0,0}$ & $0.0^{\mathrm{b}}{ }_{ \pm 0,0}$ \\
\hline \multirow[t]{3}{*}{15} & 48 & $0.0^{\mathrm{a}}{ }^{-0,0,0}$ & $0.0^{a}{ }_{ \pm 0,0}$ & $0.0^{\mathrm{b}}{ }_{ \pm 0,0}$ & $0.0^{\mathrm{b}}{ }_{ \pm 0,0}^{-0,0}$ \\
\hline & 72 & $0.0^{a}{ }^{20,0,0}$ & $0.5^{\mathrm{a}}{ }_{ \pm 0,5}^{ \pm 0,0}$ & $0.0^{\mathrm{b}}{ }_{ \pm 0,0}^{ \pm 0,0}$ & $0.0^{\mathrm{b}}{ }_{ \pm 0,0}^{0,0}$ \\
\hline & 24 & $0.0^{\mathrm{a}}{ }_{ \pm 0,0}$ & $0.0^{a}{ }_{ \pm 0,0}^{ \pm, j}$ & $0.0^{\mathrm{b}}{ }_{ \pm 0,0}^{ \pm 0,0}$ & $0.0^{\mathrm{b}}{ }_{ \pm 0,0}$ \\
\hline \multirow[t]{4}{*}{30} & 48 & $0.0^{\mathrm{a}}{ }^{-0,0,0}$ & $0.0^{a}{ }_{ \pm 0,0}$ & $0.0^{\mathrm{b}}{ }_{ \pm 0,0}$ & $0.0^{\mathrm{b}}{ }_{ \pm 0,0}$ \\
\hline & 72 & $0.0^{\mathrm{a}}{ }_{ \pm 0,0}^{ \pm 0,0}$ & $0.0^{\mathrm{a}}{ }_{ \pm 0,0}^{ \pm 0,0}$ & $0.0^{\mathrm{b}}{ }_{ \pm 0,0}^{ \pm 0,0}$ & $0.0^{\mathrm{b}}{ }_{ \pm 0,0}^{\mathrm{t}, 0}$ \\
\hline & A & $10.1 \pm 0.1$ & $12.0 \pm 0.4$ & $4.3 \pm 0.8$ & $7.7 \pm 1.1$ \\
\hline & $\mathrm{F}$ & - & - & - & \\
\hline
\end{tabular}

aqueous extracts of $S$. europaea against bacteria and yeasts were summarized in fig. 2. The highest mean inhibition zone diameter was found to be $3.8 \mathrm{~mm}$ for methanol extracts of $300 \mathrm{mg} / \mathrm{ml}$ prepared at $48 \mathrm{~h}$ incubation against $B$. subtilis followed by methanol extracts of $300 \mathrm{mg} / \mathrm{ml}$ prepared at $24 \mathrm{~h}$ incubation against $C$. albicans $(2.5 \mathrm{~mm})$ (Table 4 and Table 5).

MIC values of ethanol, methanol, acetone and aqueous extracts against all pathogens ranged from 8,35 to $4671,03 \mathrm{mg} / \mathrm{ml}$. The highest MIC value was observed against $E$. coli in methanol extract of $300 \mathrm{mg} / \mathrm{ml}$ prepared at $72 \mathrm{~h}$. The MIC values of ethanol, methanol, acetone and aqueous extracts after $24 \mathrm{~h}$ incubation with microorganisms are summarized in Table $6(\mathrm{p}<0.05)$.

The antimicrobial activity of the ethanol extract of $300 \mathrm{mg} / \mathrm{ml}$ prepared at $72 \mathrm{~h}$ against $B$. subtilis was found to be significantly different $(\mathrm{p}<0.05)$ from distilled water extract of $300 \mathrm{mg} / \mathrm{ml}$ prepared at $48 \mathrm{~h}$. the methanol extract of $300 \mathrm{mg} / \mathrm{ml}$ prepared at prepared at $24 \mathrm{~h}$ against $C$. albicans and aqueous extract of $300 \mathrm{mg} / \mathrm{ml}$ prepared at $48 \mathrm{~h}$ against $C$. parapsilosis were found to be significantly different $(\mathrm{p}<0.05)$ from other extracts.

The extracts mostly below $100 \mu 1$ showed antimicrobial activity against microorganisms. The highest MIC value was found as $8.35 \mu \mathrm{l}$ for methanol extract of $300 \mathrm{mg} / \mathrm{ml}$ prepared at $72 \mathrm{~h}$ against $E$. coli followed by acetone extract of $300 \mathrm{mg} / \mathrm{ml}$ prepared at $72 \mathrm{~h}$ against $E$. coli $(\mathrm{MIC}=8.75 \mathrm{mg} / \mathrm{ml})$, acetone extract of $300 \mathrm{mg} / \mathrm{ml}$ prepared at $72 \mathrm{~h}$ against $K$. pneumoniae (MIC $=9.11 \mathrm{mg} / \mathrm{ml}$ ), ethanol extract of $300 \mathrm{mg} / \mathrm{ml}$ prepared at $24 \mathrm{~h}$ against $S$. aureus (MIC $=9.57 \mathrm{mg} / \mathrm{ml}$ ), acetone extract of $300 \mathrm{mg} / \mathrm{ml}$ prepared at $48 \mathrm{~h}$ against C. parapsilosis $(\mathrm{MIC}=9.64 \mathrm{mg} / \mathrm{ml})$ (Table 7).

The aim of this study is to investigate the chemical and physical composition and antimicrobial activity 
TABLE 5: INHIBITION ZONE DIAMETERS OF S. europaea EXTRACTS WITH C. albicans VE C. parapsilosis ACCORDING TO THE DISC DIFFUSION METHOD.

\begin{tabular}{|c|c|c|c|}
\hline & Extracts (h) & $\begin{array}{c}\text { Inhibition Zone } \\
(\mathrm{mm})+\mathrm{SEM}^{*}\end{array}$ & \\
\hline $\begin{array}{l}\text { Weight } \\
\text { (g) }\end{array}$ & acetone & C. albicans & C. parapsilosis \\
\hline \multirow{4}{*}{15} & 24 & $2.0^{\mathrm{a}}{ }_{ \pm 1,0}$ & $0.0^{\mathrm{b}}{ }_{ \pm 0,0}$ \\
\hline & 48 & $0.8^{a}{ }_{ \pm 0,7}^{ \pm 1,0}$ & $0.0^{\mathrm{b}}{ }_{ \pm 0,0}$ \\
\hline & 72 & $2.2^{a}{ }_{ \pm 1,1}$ & $0.0^{\mathrm{b}}{ }_{ \pm 0,0}$ \\
\hline & 24 & $0.2^{a}{ }_{ \pm 0,1}$ & $0.1^{\mathrm{a}}{ }_{ \pm 0,0}$ \\
\hline \multirow[t]{4}{*}{30} & 48 & $0.0^{a^{-}{ }_{ \pm 0,0}}$ & $0.1^{\mathrm{a}}{ }_{ \pm 0,0}$ \\
\hline & 72 & $0 \cdot 1^{a}{ }_{ \pm 0,1}$ & $0.0^{\mathrm{b}}{ }_{ \pm 0,0}^{ \pm 0,0}$ \\
\hline & ethanol & & \\
\hline & 24 & $1 \cdot 4^{\mathrm{a}}{ }_{ \pm 1,3}$ & $0.0^{\mathrm{b}}{ }_{ \pm 0,0}$ \\
\hline \multirow[t]{3}{*}{15} & 48 & $1.1^{\mathrm{a}}{ }_{ \pm 0,6}$ & $0.0^{\mathrm{b}}{ }_{ \pm 0,0}^{ \pm 0,0}$ \\
\hline & 72 & $1.4^{\mathrm{a}}{ }_{+0,5}$ & $0.0^{\mathrm{b}}{ }_{ \pm 0,0}$ \\
\hline & 24 & $1.0^{a}{ }_{ \pm 0,8}$ & $0.0^{\mathrm{b}}{ }_{ \pm 0,0}^{ \pm 0}$ \\
\hline \multirow[t]{4}{*}{30} & 48 & $2.8^{a}+0.5$ & $0.0^{\mathrm{b}}+0,0$ \\
\hline & 72 & $1.5^{\mathrm{a}}{ }_{ \pm 1,3}^{ \pm 0,3}$ & $0.0^{\mathrm{b}}{ }_{ \pm 0,0}^{ \pm 0,0}$ \\
\hline & methanol & & \\
\hline & 24 & $0.0^{a}$ & $0.0^{\mathrm{b}}$ \\
\hline \multirow[t]{3}{*}{15} & 48 & $0.0^{a}{ }_{ \pm 0,0}$ & $0.0^{\mathrm{b}}{ }_{ \pm 0,0}$ \\
\hline & 72 & $0.0^{a}{ }_{ \pm 0,0}^{ \pm 0,0}$ & $0.0^{\mathrm{b}}{ }_{ \pm 0,0}^{ \pm 0,0}$ \\
\hline & 24 & $2.5^{\mathrm{a}}{ }_{ \pm 0,9}$ & $0.0^{\mathrm{b}}{ }_{ \pm 0,0}$ \\
\hline \multirow[t]{4}{*}{30} & 48 & $2.3^{a}{ }_{ \pm 2,3}$ & $0.0^{\mathrm{b}}{ }_{ \pm 0,0}$ \\
\hline & 72 & $0.7^{a}{ }_{ \pm 0,7}$ & $0.0^{\mathrm{b}}{ }_{ \pm 0,0}$ \\
\hline & aqueous & & \\
\hline & 24 & $0.0^{\mathrm{a}}{ }_{ \pm 0,0}$ & $0.0^{\mathrm{b}}{ }_{ \pm 0,0}$ \\
\hline \multirow[t]{3}{*}{15} & 48 & $0.0^{a_{ \pm 0,0}}$ & $0.0^{\mathrm{b}}{ }_{ \pm 0,0}$ \\
\hline & 72 & $0.0^{\mathrm{a}}{ }_{ \pm 0,0}$ & $0.0^{\mathrm{b}}{ }_{ \pm 0,0}$ \\
\hline & 24 & $0.4^{a}{ }_{ \pm 0,4}^{-3,0}$ & $0.0^{\mathrm{b}}{ }_{ \pm 0,0}$ \\
\hline \multirow[t]{4}{*}{30} & 48 & $0.0^{\mathrm{a}}{ }_{ \pm 0,0}$ & $0.0^{\mathrm{b}}{ }_{ \pm 0,0}$ \\
\hline & 72 & $0.0^{a}{ }_{ \pm 0,0}$ & $0.0^{\mathrm{b}}{ }_{ \pm 0,0}$ \\
\hline & A & - & - \\
\hline & $\mathbf{F}$ & $1.1 \pm_{0.18}$ & $2.4 \pm_{0.1}$ \\
\hline
\end{tabular}

of $S$. europaea for pharmaceuticals and cosmeceutical applications. Therefore, GC-MS, ICP/MS and LC/MSMS analyzes are performed to determine its chemical composition, while 4 bacteria E. coli, $K$. pneumonia, $B$. subtilis, $S$. aureus and 2 fungi (C. albicans, C. parapsilosis) are used to determine antimicrobial and antifungal activation.

The hexane-extracted oil content of fresh S. europaea cultivated was found to be $15.15 \%$. Anwar et al. ${ }^{[13]}$ investigated the analytical characterization of seed oil of Salicornia. bigelovii and found oil percentage to be $29.2 \%$. Eganathan et al. ${ }^{[14]}$ reported $22.4 \%$ oil in seeds of S. brachiate by using hexane-extracted. Anwar et al. ${ }^{[13]}$ examined analytical characterization of Salicornia. bigelovii seed oil and found as $13.42 \%$ which is lower than the present study. In the moisture analysis, the humidity rate of $S$. europaea was $8 \%$. Min et al. ${ }^{[15]}$ studied chemical composition of Salicornia. herbacea and reported moisture content as $9.09 \%$ that is similar to the present study. The amount of $\mathrm{Na}, \mathrm{Mg}, \mathrm{K}, \mathrm{Ca}$ minerals in the $S$. europaea were 447, 51. 98, 45.86, $14.27 \mathrm{ppm}$ respectively according to ICP/MS and EDX. Austenfeld et al. ${ }^{[16]}$ reported $\mathrm{Ca}$ and $\mathrm{Mg}$ content in the seeds of S. europaea to be 30 and $138 \mathrm{mmol}$ respectively. Lima et al. ${ }^{[17]}$ studied the mineral compositions of Salicornia ramosissima species grown at different salinity rates for $\mathrm{Na}, \mathrm{K}, \mathrm{Ca}, \mathrm{Mg}$ found to be $8.36-17.4 \mathrm{mg} / \mathrm{g}$, $1.41-2.23 \mathrm{mg} / \mathrm{g}, 0.41-1.45 \mathrm{mg} / \mathrm{g}$ and $0.17-0.23 \mathrm{mg} / \mathrm{g}$ respectively. Bertin et al. ${ }^{[18]}$ investigated $\mathrm{Na}, \mathrm{K}, \mathrm{Mg}$ and $\mathrm{Ca}$ in Sarcocornia ambigua collected from two different localities and reported that mineral contents of $\mathrm{Na}, \mathrm{K}, \mathrm{Mg}$ and $\mathrm{Ca}$ were found as $10.19 \mathrm{mg} / \mathrm{g}$, $2.9 \mathrm{mg} / \mathrm{g}, 0.92 \mathrm{mg} / \mathrm{g}$ ve $0.54 \mathrm{mg} / \mathrm{g}$ from Palhoça beach, and $16.57 \mathrm{mg} / \mathrm{g}, 1.81 \mathrm{mg} / \mathrm{g}, 1.30 \mathrm{mg} / \mathrm{g}$ ve $0.53 \mathrm{mg} / \mathrm{g}$ from Barra da Lagoa respectively. Yabalak et al. ${ }^{[19]}$ examined mineral and trace elements from the methanolic extract of Arum dioscoridis sm. by using ICP-MS, and found the mineral content for $\mathrm{Na}, \mathrm{Mg}, \mathrm{K}$ and $\mathrm{Ca}$ as $636.0 \mathrm{ppm}$, $1301.4 \mathrm{ppm}, 4142.0 \mathrm{ppm}$ and $14406.6 \mathrm{ppm}$ respectively. Yabalak et al. ${ }^{[20]}$ studied trace element content of O. munzurense that $\mathrm{Na}, \mathrm{K}, \mathrm{Mg}$, Ca concentrations were as $13.13,128.1,38.3$ and $161.57 \mathrm{ppm}$ respectively. The regional differences in the soil and plant structure are effective in the elemental composition of a plant which then may be the reason of the detected the low concentration in the present study compared to the given other studies.

There have been several studies conducted on the antimicrobial activity of seagrasses metabolites for many years ${ }^{[21-23]}$. Some seagrasses species such as Halodule pinifolia and Cymodocea rotundata have predominant antimicrobial agents against $S$. aureus, Vibrio cholerae, Shigella dysenteriae, Salmonella paratyphi and Shigella boydii ${ }^{[24]}$. Kumar et al. ${ }^{[25]}$ reported the antibacterial properties of different extracts of Cymodocea serrulata, Halophila ovalis and Zostera capensis tested against some pathogens such as S. aureus, Bacillus cereus, B. subtilis and the best activity were seen in ethyl acetate and methanol extract. Similarly in the present study, methanol extract was more active than the others against microorganism according to disc diffusion method.

Essaidi et al ${ }^{[26]}$ reported that antibacterial performance of the methanolic extract of $S$. herbacea against some pathogens by disc diffusion method. While the extract of $20 \mathrm{mg} / \mathrm{ml}$ had not any activity on E. coli and 
TABLE 6: MIC VALUES OF $S$. aureus EXTRACTS INCUBATED SEPARATELY WITH E. Coli, $K$. pneumoniae, $B$. subtilis and $S$. aureus FOR 24 H ACCORDING TO SPECTROPHOTOMETRIC MICRODILUTION METHOD

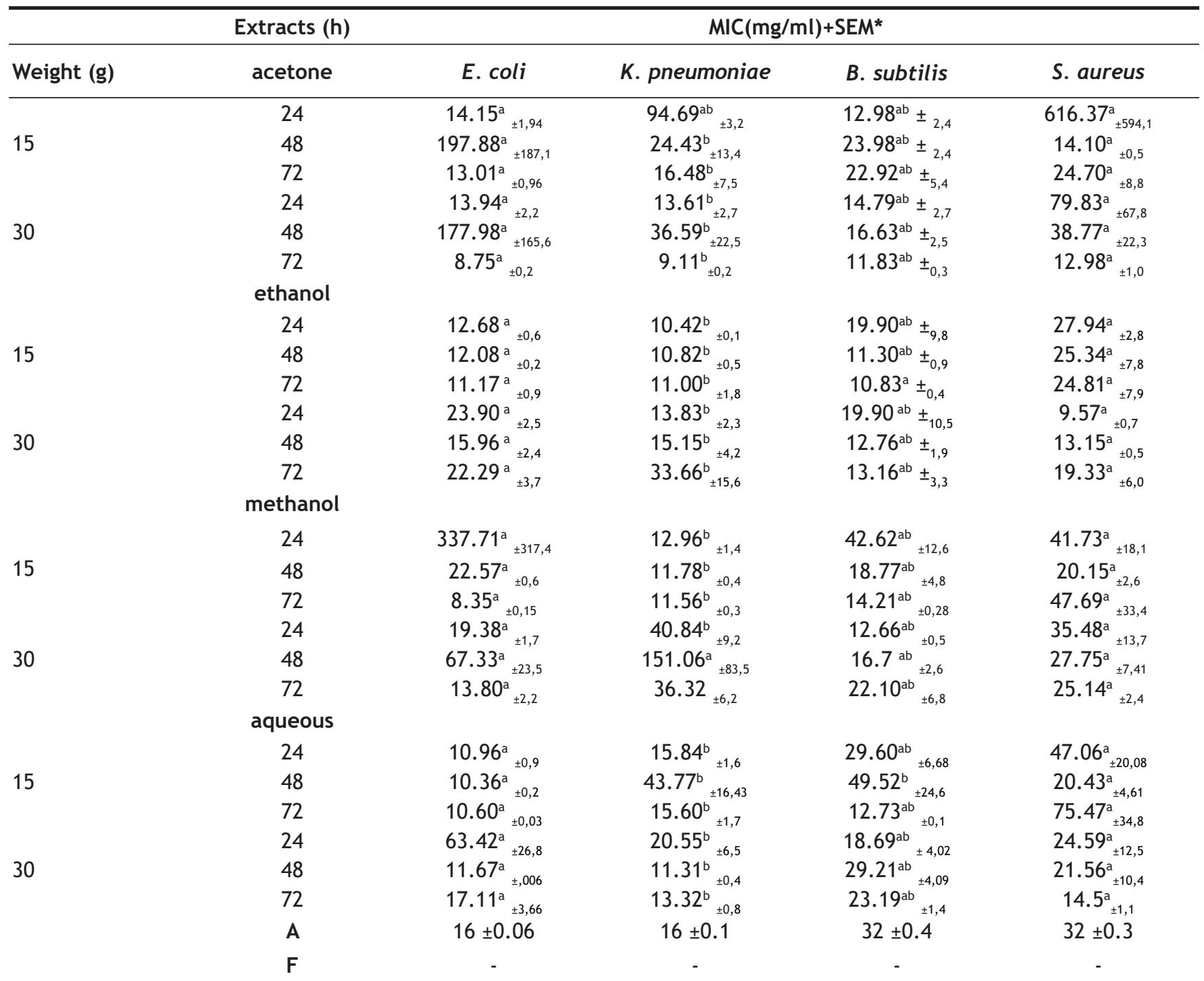

*SEM: Standard error of the mean. Mean MICs, standard deviation ( \pm ) and significance level were expressed by Tukey test (ANOVA, $P<0.05)$. In the same column, values marked with different exponential letters differ statistically at 0.05 level. A: Ampicillin $(16 \mu g / m L)$, F: Fluconazole $(1280 \mu \mathrm{g} / \mathrm{mL})$

K. pneumoniae after $24 \mathrm{~h}$ incubation, the extract of $100 \mathrm{mg} / \mathrm{ml}$ inhibited them between 6 and $10 \mathrm{~mm}$ zone ${ }^{[26]}$. In our study, we reported that methanolic extract of $300 \mathrm{mg} / \mathrm{ml}$ had 1.5 and $0.0 \mathrm{~mm}$ zone against $E$. coli and K. pneumoniae. Santhanakrishnan et al. ${ }^{[27]}$ reported that the MIC values of methanolic extract of $S$. brachiata against B. subtilis and K. pneumoniae were 25 and $50 \mathrm{mg} / \mathrm{ml}$, respectively. The MIC values of $S$. europaea as $12.96 \mathrm{mg} / \mathrm{ml}$ and $42.62 \mathrm{mg} / \mathrm{ml}$ for B. subtilis and $K$. pneumonia were relatively lower.

Rahmani and Heydarian ${ }^{[28]}$ indicated that the ethanolic extract (70 \%) of Salicornia iranica had no antifungal activity against Aspergillus niger and Candida albicans at the end of the at $25^{\circ}$ for $72 \mathrm{~h}$ incubation. The negative effect was related to the lack of fatty acid methyl esters in ethanolic extract ${ }^{[28]}$. However, we determined the various inhibition zones of $S$. europaea ethanol extract against $C$. albicans at 24, 48 and $72 \mathrm{~h}$ incubations. For the concentration of $300 \mathrm{mg} / \mathrm{ml}$, the minimum zone $(1.0 \mathrm{~mm})$ was at $24 \mathrm{~h}$ incubations while the maximum zone $(2.8 \mathrm{~mm})$ was at $48 \mathrm{~h}$ incubations which indicate that Salicornia species have different contents of ethanol extracts. In another study, the ethanol extract of $S$. herbacea seed inhibited $S$. aureus with MIC of $189.5 \mathrm{mg} / \mathrm{ml}$ and E. coli $420 \mathrm{mg} / \mathrm{ml}^{[29]}$. Whereas, we showed that maximum inhibition concentration was related to $S$. aureus with MIC of $9.57 \mathrm{mg} / \mathrm{ml}$ at $24 \mathrm{~h}$ incubation and E. coli with MIC of $11.17 \mathrm{mg} / \mathrm{ml}$ at $72 \mathrm{~h}$ incubation, respectively.

In summary, the present results revealed bioactive compounds of $S$. europaea, especially its richness in oil and oleic acid. Besides, S. europaea extracts 
TABLE 7: MIC VALUES OF S. EUROPAEA EXTRACTS INCUBATED SEPARATELY WITH C. albicansve, C. parapsilosis FOR 24 HACCORDING TO SPECTROPHOTOMETRIC MICRODILUTION METHOD

\begin{tabular}{|c|c|c|c|}
\hline \multirow{2}{*}{$\begin{array}{l}\text { Weight } \\
\text { (g) }\end{array}$} & \multirow{2}{*}{$\begin{array}{c}\text { Extracts }(\mathrm{h}) \\
\text { acetone }\end{array}$} & \multicolumn{2}{|c|}{$\mathrm{MIC}(\mathrm{mg} / \mathrm{mL})+\mathrm{SEM} *$} \\
\hline & & C. albicans & C. parapsilosis \\
\hline \multirow{4}{*}{15} & 24 & $10.32^{\mathrm{b}}{ }_{ \pm 0,1}$ & $15.64^{b}{ }_{ \pm 1,8}$ \\
\hline & 48 & $14.84^{\mathrm{b}}{ }_{ \pm 1,9}$ & $9.64^{\mathrm{b}}{ }_{ \pm 0,04}$ \\
\hline & 72 & $30.76^{\mathrm{b}}{ }_{ \pm 2,4}$ & $15.00^{\mathrm{b}}{ }_{ \pm 2,8}$ \\
\hline & 24 & $21.00^{\mathrm{b}}{ }_{ \pm 5,0}$ & $18.04^{\mathrm{b}}{ }_{ \pm 0,2}$ \\
\hline \multirow[t]{4}{*}{30} & 48 & $366.09^{b}$ & $15.36^{\mathrm{b}}{ }_{+0,6}$ \\
\hline & 72 & $30.05^{b} \underset{ \pm 13,7}{ }$ & $41.53_{ \pm 2,3}^{b}$ \\
\hline & ethanol & & \\
\hline & 24 & $58.24_{ \pm 47,8}^{\mathrm{b}}$ & $19.24_{ \pm 4,1}^{b}$ \\
\hline \multirow[t]{3}{*}{15} & 48 & $15.25^{\mathrm{b}}{ }_{ \pm 2,6}$ & $17.05^{\mathrm{b}}+2,7$ \\
\hline & 72 & $15.59^{\mathrm{b}}{ }_{ \pm 5,06}$ & $20.12^{\mathrm{b}}{ }_{ \pm 2,5}$ \\
\hline & 24 & $24.71^{\mathrm{b}}{ }_{ \pm 3,30}$ & $18.38^{\mathrm{b}}{ }_{ \pm 5,04}$ \\
\hline \multirow[t]{4}{*}{30} & 48 & $16.40^{\mathrm{b}}{ }_{ \pm 0,37}$ & $17.14_{ \pm 1,4}^{\mathrm{b}}$ \\
\hline & 72 & $11 \cdot 30^{\mathrm{b}}{ }_{ \pm 0,33}$ & $13.28^{\mathrm{b}}{ }_{ \pm 0,06}$ \\
\hline & methanol & & \\
\hline & 24 & $4671.03^{\mathrm{a}}{ }_{ \pm 33792}$ & $68.18 b_{ \pm 5,5}$ \\
\hline \multirow[t]{3}{*}{15} & 48 & $18.71_{ \pm 0,3}^{\mathrm{b}}$ & $41 \cdot 30^{\mathrm{b}}{ }_{ \pm 18,58}$ \\
\hline & 72 & $16.80_{ \pm 3,1}^{\mathrm{b}}$ & $22.16^{\mathrm{b}}{ }_{ \pm 1,7}$ \\
\hline & 24 & $17.32^{\mathrm{b}}{ }_{ \pm 1,45706}$ & $22 \cdot 30^{\mathrm{b}}{ }_{ \pm 7,01}$ \\
\hline \multirow[t]{4}{*}{30} & 48 & $152 \cdot 25^{\mathrm{b}}{ }_{ \pm 45,01}$ & $83.95^{\mathrm{b}}{ }_{ \pm 58,8}$ \\
\hline & 72 & $11.13^{\mathrm{b}}{ }_{ \pm, 14}$ & $22.78_{ \pm 1,8}^{\mathrm{b}}$ \\
\hline & aqueous & & \\
\hline & 24 & $25.82^{\mathrm{b}}{ }_{ \pm 10,9}$ & $25.85_{ \pm 7,5}^{\mathrm{b}}$ \\
\hline \multirow[t]{3}{*}{15} & 48 & $18 \cdot 38^{\mathrm{b}}{ }_{ \pm 6,2}$ & $623.10^{\mathrm{a}}{ }_{ \pm 307,2}$ \\
\hline & 72 & $1576.49^{\mathrm{b}}{ }_{ \pm 15231}$ & $74.63^{\mathrm{b}}{ }_{ \pm 31,5}$ \\
\hline & 24 & $20.21^{\mathrm{b}}{ }_{ \pm 3,3}$ & $21.15^{\mathrm{b}}{ }_{ \pm 0,3}$ \\
\hline \multirow[t]{4}{*}{30} & 48 & $21.13_{ \pm 1,9}^{\mathrm{b}}$ & $15.26^{\mathrm{b}}{ }_{ \pm 4,2}$ \\
\hline & 72 & $121.76^{\mathrm{b}}{ }_{ \pm 101,9}$ & $13.89^{b}{ }_{ \pm 2,6}$ \\
\hline & A & - & - \\
\hline & $F$ & $128 \pm 3.5$ & $128 \pm 0.5$ \\
\hline
\end{tabular}

*SEM: Standard error of the mean. Mean MICs, standard deviation $( \pm)$ and significance level were expressed by Tukey test (ANOVA, $P<0.05)$. In the same column, values marked with different exponential letters differ statistically at 0.05 level. A: Ampicillin $(16 \mu \mathrm{g} / \mathrm{mL})$, F: Fluconazole $(1280 \mu \mathrm{g} / \mathrm{mL})$

prepared with ethanol, methanol, acetone and aqueous exhibit a potent antimicrobial and antifungal effect against several pathogenic microorganisms. Especially, the methanol extract showed a high effect against pathogens. Therefore, extract and oil of S. europaea can be a new source of bioactive compounds for pharmaceuticals and cosmeceutical applications.

\section{Acknowledgments:}

This is a part of S. Karan's PhD Thesis. Thanks to the Scientific \& Technological Research Council of Turkey
(TUBITAK-2211/C National PhD Scholarship Program for Priority Areas) for support. Part of the study is presented in the International Cosmetic Congress "Green Cosmetics" 28-30 October 2018, Antalya/ Turkey.

\section{Research funding:}

We are grateful to the Iskenderun Technical University Scientific Research Projects Office for their financial support (Project No. 2020LTP-01).

\section{Author contribution:}

All the authors have accepted responsibility for the entire content of this submitted manuscript and approved submission.

\section{Conflict of Interest:}

No conflict of interest declared.

\section{REFERENCES}

1. Davy AJ, Bishop GF, Costa CS. Salicornia L.(Salicornia pusilla J. woods, S. ramosissima J. woods, S. europaea L., S. obscura PW ball \& tutin, $S$. nitens PW ball \& tutin, $S$. fragilis PW ball \& tutin and $S$. dolichostachya moss). J Ecol 2001;89(4):681-707.

2. Piirainen M. Flora Nordica notes. 1. Salicornia (Chenopodiaceae) in northern Europe: Typification and taxonomic notes. In: Annales Botanici Fennici 1991;81-85.

3. Seçmen Ö, Leblebici E. Türkiye Sulak Alan Bitkileri ve Bitki Örtüsü. Ege Üniversitesi Fen Fakültesi Yayınları No: 158, İzmir, 1997.

4. Lubbe A, Verpoorte R. Cultivation of medicinal and aromatic plants for specialty industrial materials. Ind Crop Product 2011;34(1):785-801

5. Lin TJ. Manufacturing cosmetic emulsions: pragmatic troubleshooting and energy conservation. Alluredbooks; 2010.

6. Chemat F, Vian MA, Cravotto G. Green extraction of natural products: concept and principles. Int $\mathrm{J}$ Mol Sci. 2012;13(7):8615-27.

7. Aswal A, Kalra M, Rout A. Preparation and evaluation of polyherbal cosmetic cream. Pharma Lett 2013;5(1):83-8.

8. Biologicals D. McFarland Standard for in vitro use only. DALYNN biologicals 2014.

9. Yabalak E, Ibrahim F, EliuzEA, EverestA, GizirAM. Evaluation of chemical composition, trace element content, antioxidant and antimicrobial activities of Verbascum pseudoholotrichum. Plant Biosystems Int J Plant Biol 2020;27:1-4.

10. Patton T, Barrett J, Brennan J, Moran N. Use of a spectrophotometric bioassay for determination of microbial sensitivity to manuka honey. J Microbiol Method 2006;64(1):84-95.

11. Erdoğan Eliuz EA, Ayaş D, Gökşen G. In vitro photo toxicity and antimicrobial activity of volatile oil obtained from aromatic plants. J Essent Oil Bear 2017;20:758-68.

12. Johnson W, Bergfeld WF, Belsito DV, Hill RA, Klaassen CD, Liebler DC, et al. Safety Assessment of Tin (IV) Oxide as Used in Cosmetics. Int J Toxicol 2014;33(4): 40-46. 
13. Anwar F, Bhanger MI, Nasir MKA, Ismail S. Analytical characterization of Salicornia bigelovii seed oil cultivated in Pakistan. J Agric Food Chem 2002;50(15):4210-4.

14. Eganathan P, Subramanian HS, Latha R, Rao CS. Oil analysis in seeds of Salicornia brachiata. Ind Crops Prod 2006;23(2):1779.

15. Min JG, Lee DS, Kim TJ, Park JH, Cho TY, Park DI. Chemical Composition of Salicornia herbacea L. Prev Nutr Food Sci 2002;71:105-7.

16. Austenfeld FA. Nutrient reserves of Salicornia europaea seeds. Physiol Plant 1986;683:446-50.

17. Lima AR, Castañeda-Loaiza V, Salazar M, Nunes C, Quintas $\mathrm{C}$, Gama $\mathrm{F}$, et al. Influence of cultivation salinity in the nutritional composition, antioxidant capacity and microbial quality of Salicornia ramosissima commercially produced in soilless systems. Food Chem 2020;333:127525.

18. Bertin RL, Gonzaga LV, Borges GD, Azevedo MS, Maltez HF, Heller M, et al. Nutrient composition and identification/ quantification of major phenolic compounds in Sarcocornia ambigua (Amaranthaceae) using HPLC-ESI-MS/MS. Food Res Int 2014;55:404-11.

19. Yabalak E. Radical scavenging activity and chemical composition of methanolic extract from Arum dioscoridis sm. var. dioscoridis and determination of its mineral and trace elements. J Turkish Chem Soc Section A Chemistry 2018;5(1):205-18.

20. Yabalak E, Emire Z, Adıgüzel AO, Könen Adıgüzel S, Gizir AM. Wide-scale evaluation of Origanum munzurense Kit Tan \& Sorger using different extraction techniques: Antioxidant capacity, chemical compounds, trace element content, total phenolic content, antibacterial activity and genotoxic effect. Flavour Fragrance J 2020;35(4):394-410.

21. Rowley DC, Hansen MS, Rhodes D, Sotriffer CA, Ni H, McCammon JA, et al. Thalassiolins A-C: new marine-derived inhibitors of HIV cDNA integrase. Bioorganic Med Chem 2002;10(11):3619-25.

22. Kannan RRR, Arumugam R, Anantharaman P. Antibacterial potential of three seagrasses against human pathogens. Asian Pac J Trop Med 2010;311:890-3.

23. Kannan RRR, Arumugam R, Anantharaman P. Chemical composition and antibacterial activity of Indian seagrasses against urinary tract pathogens. Food chem 2012;1354:2470-3.

24. Kannan RRR, Arumugam R, Iyapparaj P, Thangaradjou T, Anantharaman P. In vitro antibacterial, cytotoxicity and haemolytic activities and phytochemical analysis of seagrasses from the Gulf of Mannar, South India. Food chem 2013;136(34):1484-9.

25. Kumar CS, Sarada DV, Gideon TP, Rengasamy R. Antibacterial activity of three South Indian seagrasses, Cymodocea serrulata, Halophila ovalis and Zostera capensis. World J Microb Biotech 2008;24(9):1989-92.

26. Essaidi I, Brahmi Z, Snoussi A, Koubaier HBH, Casabianca $\mathrm{H}$, Abe $\mathrm{N}$, et al. Phytochemical investigation of Tunisian Salicornia herbacea L., antioxidant, antimicrobial and cytochrome P450 (CYPs) inhibitory activities of its methanol extract. Food Control 2013;32(1):125-33.

27. Santhanakrishnan D, Shankar SN, Chandrasekaran B. Studies on the phytochemistry, spectroscopic characterization and antibacterial efficacy of Salicornia brachiata. Int J Pharm Pharm Sci 2014;6(6):430-2.

28. Rahmani N, Heydarian Z. Investigation of in vitro antifungal activity of Salicornia iranica Akhani. Trad Integr Med 2016;1(1):44-6.

29. Sharifi-Rad J, Hoseini-Alfatemi SM, Sharifi-Rad M. In vitro assessment of antibacterial activity of Salicornia herbacea L. seed extracts against multidrug resistant grampositive and gram-negative bacteria. Int J Biosci 2004;4(6):217-22. 